\title{
GENETIC DIVERSITY OF PASSIFLORA ACCESSIONS BASED ON MORPHOPHYSIOLOGICAL SEED DESCRIPTORS ${ }^{1}$
}

\author{
THALITA NEVES MAROSTEGA ${ }^{2}$, LOURISMAR MARTINS ARAUJO $^{3}$, \\ PETTERSON BAPTISTA DA LUZ ${ }^{4}$, LEONARDA GRILLO NEVES ${ }^{4}$, \\ MARCO ANTÔNIO APARECIDO BARELLI ${ }^{4}$
}

\begin{abstract}
The aim of this work was to estimate the genetic divergence among Passiflora accessions based on morphophysiological seed characteristics. Accessions were distributed in a completely randomized design, with four replicates of 25 seeds. Data were submitted to analysis of variance and the means grouped by the Scott-Knott method. The genetic diversity was studied according to the Tocher and UPGMA grouping method based on the Mahalanobis distance $\left(\mathrm{D}^{2}\right)$ and Canonical Variables. In the cluster analyzes, four groups were formed by the UPGMA and Canonical Variables methods. In the Tocher Optimization method, seven groups were formed. of $P$. eichleriana, $P$. suberosa, $P$. edulis and $P$. foetida accessions presented the best results for the seed characteristics under study, being indicated for interspecific crosses aiming the selection of materials that present less dormancy and with more vigorous seeds.
\end{abstract}

Index terms: passion fruit tree, variability, wild, grouping method.

\section{DIVERSIDADE GENÉTICA DE ACESSOS DE Passiflora COM BASE EM DESCRITORES MORFOFISIOLÓGICOS DE SEMENTE}

RESUMO - O objetivo deste trabalho foi estimar a divergência genética entre acessos de Passiflora com base em características morfofisiológicas da semente. Os acessos foram distribuídos em delineamento inteiramente casualizado, com quatro repetições de 25 sementes. Os dados obtidos foram submetidos à análise de variância e as médias agrupadas pelo método Scott-Knott. A diversidade genética foi estudada de acordo com o método de agrupamento de Tocher e UPGMA, baseado na distância de Mahalanobis $\left(\mathrm{D}^{2}\right)$ e Variáveis Canônicas. Nas análises de agrupamento, foram formados quatro grupos pelos métodos UPGMA e Variáveis Canônicas. No método de Otimização de Tocher foram formados sete grupos. Os acessos das espécies $P$. eichleriana, P. suberosa, P. edulis e P. foetida apresentaram os melhores resultados para as características de semente estudadas, sendo indicados para cruzamentos interespecíficos, visando seleção de materiais que apresentem sementes menos dormentes e mais vigorosas.

Termo para indexação: maracujazeiro, variabilidade, silvestre, método de agrupamento.

\footnotetext{
${ }^{1}$ (Paper 110-16). Received August 25, 2016. Accepted Februrary 14, 2017.

${ }^{2} \mathrm{PhD}$ student at the Federal University of Mato Grosso. Avenida Fernando Correia da Costa, 2367-Boa Esperança, Cuiabá-MT, 78060-900. E-mail: tamarostega@gmail.com

${ }^{3}$ Me.Federal Institute of Mato Grosso. Line J, s / n ${ }^{\circ}$, Sector Chácara, Juiná-MT, 78320-000. E-mail: lourismar1@hotmail.com

${ }^{4}$ Dr. of the State University of Mato Grosso. Avenida Santos Dumont, s / ${ }^{\mathrm{o}}$, Cidade Universitária, CáceresMT, 78200-000. E-mails: petterbaptista@yahoo.com.br; mbarelli@unemat.br; leonardaneves@unemat.br.
} 


\section{INTRODUCTION}

The Passifloraceae family comprises about 18 genera and 630 species predominantly distributed in tropical and subtropical areas, mainly in the Americas and Africa (AZEVEDO and BAUMGRATZ, 2004). In Latin America, the most representative genus is Passiflora, with approximately 400 species, of which 150 are found in Brazil (BERNACCI et al., 2013). This puts the country in a privileged position as regards the genetic resources of this genus that can be exploited in breeding programs.

Accurate and detailed studies of the genetic variability of passion fruit may indicate valuable genetic resources, either through the introduction of new species into production systems or genes of wild species useful to improve currently cultivated species (SANTOS, 2015).

Thus, genetic variability can be verified by the use of several types of descriptors, among which, the most important are morphological and physiological (CRUZ et al., 2011). In this sense, seed quality descriptors are also highlighted, because they are subject to a series of degenerative changes after maturation, which are associated with vigor reduction (BEWLEY, et al., 2014).

Thus, the present work was developed with the aim of estimating the genetic divergence among Passiflora accessions present in the Germplasm Active Bank of the State University of Mato Grosso based on morphophysiological seed characteristics.

\section{MATERIAL AND METHODS}

\section{Genetic material}

Two commercial Passiflora accessions ( $P$. alata and $P$ edulis) and 10 wild ones present in the Germoplasma Active Bank (BAG), State University of Mato Grosso (UNEMAT) (Table 1), were evaluated.

\section{Procedures}

Fruits were harvested during the maturation period, and seeds were manually extracted by rubbing them in running water with hydrated lime on wire sieve $(3 \mathrm{~mm})$. After extraction, seeds were dried in the shade on newspaper for two days at room temperature and stored in transparent glass bottles, sealed and kept in cold chamber at temperature of $7^{\circ} \mathrm{C}$ until use.

Germination test, germination speed index, seedling emergence percentage, emergence speed index, seedling dry mass, radicle length of normal seedlings, seed length and mass of 1000 seeds were used for seed characterization.

For the germination test, the water content of seeds was initially quantified to ensure that it did not interfere with the result. Another measure taken was seed asepsis in $70 \%(\mathrm{v} / \mathrm{v})$ alcohol solution for 1 minute, and then in sodium hypochlorite $(2.5 \%$ active chlorine) for 5 minutes, being finally washed in distilled water.

\section{Description of Variables}

Mass of one thousand seeds:

The mass of one thousand seeds was determined by the random counting of eight sub-samples of 100 seeds, which were weighed, and the values of one thousand seeds were expressed in grams, with one decimal place (BRASIL, 2009).

\section{Germination test:}

Four replicates of 25 seeds were transferred to transparent "Gerbox" boxes on three sheets of paper towel ("Germitest") moistened with distilled water in the proportion of two and a half times the paper weight. To maintain humidity, boxes were placed in transparent polyethylene bags and placed in a germination chamber with temperature alternation of $20-30^{\circ} \mathrm{C}$ and 12 -hour photoperiod (12 hours of light at $30^{\circ} \mathrm{C}$ ) for 30 days (BRASIL, 2009).

\section{Germination speed index:}

Following the methodology prescribed for the germination test, monitoring was carried out every day at the same time, and the seed that broke the tegument and emitted radicles at least $2 \mathrm{~mm}$ long was considered germinated (HADAS, 1976). Evaluations were performed until the time of the last count (at 30 days), and the speed index was calculated according to Maguire (1962).

\section{Seedling emergence percentage:}

The test was performed in laboratory with room temperature (minimum of $19.2^{\circ} \mathrm{C}$ and maximum of $31.6^{\circ} \mathrm{C}$ ). For the tests, four sub-samples of 25 seeds were used, distributed in trays filled with substrate (vermiculite). Evaluation was performed 30 days after sowing, computing normal emerged seedlings, and the result was expressed as percentage.

\section{Seedling emergence speed:}

The test was performed in laboratory at room temperature (minimum $19.2^{\circ} \mathrm{C}$ and maximum $31.6^{\circ} \mathrm{C}$ ). For the tests, four sub-samples of 25 seeds were used, distributed in trays filled with substrate 
(vermiculite). Daily evaluations were performed for 30 days after sowing. Seedlings with totally free cotyledons were considered as emerged. Seedling emergence speed was calculated according to Maguire (1962).

\section{Radicle length of seedlings:}

Te test was carried out using normal seedlings from the emergence test. Evaluation was performed on the thirtieth day after sowing, measuring normal seedlings with millimeter ruler. The result was expressed in $\mathrm{cm}$ of radicle / seedling.

\section{Seedling dry mass:}

After the emergence test, the fresh and dry mass of seedlings was determined. On the thirtieth day after sowing, normal seedlings were packed in paper bags and taken to an air circulation oven at $70^{\circ}$ $\mathrm{C}$ for 72 hours. Weighing was performed before and after drying to calculate the average weight of fresh and dry mass, expressed in $\mathrm{mg} /$ seedling.

\section{Seed length:}

For the determination of the seed length, seeds were measured using a digital caliper and the result expressed in $\mathrm{cm}$.

\section{Statistical analysis}

First, data were submitted to the ShapiroWilk normality test using the R statistical software version 2.15.2 (R CORE TEAM, 2012).

The germination percentage, germination speed index, emergence percentage, emergence speed index, seedling dry mass and radicle length data were transformed into $\sqrt{x}+0.5$. Data were statistically interpreted through analysis of variance and the means grouped by Scott-Knott's test $(\mathrm{P} \leq 0.05)$ using the SISVAR software (FERREIRA, 2008).

The genetic divergence among accessions was evaluated by multivariate analysis, using as a measure of dissimilarity the generalized Mahalanobis distance $\left(\mathrm{D}^{2}{ }_{\mathrm{ii}}\right)$, adopting the criterion in which the average of genetic divergence measures within each group should be lower than the average distances between any groups.

Thus, to facilitate the interpretation of dissimilarity measure among accessions, the Tocher Optimization grouping methods, the UPGMA (Unweighted pair-group method with common average) and Canonic Variables analysis were used, processed through the GENES computer software (CRUZ, 2016).

\section{RESULTS AND DISCUSSIONS}

Through analysis of variance, it was observed that there was a significant difference among means of accessions by the $\mathrm{F}$ test for all variables under study.

By means of comparison of means, it was verified that $P$. edulis species had the highest germination and germination speed index values ( $93 \%$ and 2.76). P. suberosa (49\%), P. eichleriana (39\%) and P. foetida (31\%) species also presented germination; however, below 50\% (Table 2).

Regarding the seedling emergence percentage, accessions 7 (P. mucronata) and 1 (P. quadrangularis) were grouped as the best results, $54 \%$ and $50 \%$, respectively, according to the Skott-Knott test. However, for the emergence speed index, accession 4 (P. eichleriana) was statistically superior to the others (Table 2).

According to Tekrony and Egli (1991), seedling vigor is observed by the ability of the seed to emerge and grow quickly and vigorously, being a characteristic that can influence crop productivity. In the same perspective, Melo et al. (2000) reported that in the medium and long term, the genetic improvement of Passiflora spp. should select plants in populations considering the seed germination rate, in addition to other agronomic characteristics.

Variables seed fresh mass and seed length were those that discriminated the studied accessions better, forming 11 and 9 groups respectively for these variables.

Based on the relative magnitude of $\mathrm{D}^{2}$ values, it was verified that, through the Tocher Optimization method, seven distinct groups were formed: IV (P. mucronata), V (P. alata), VI (P. edulis) and VII ( $P$. foetida) formed by only one accession each, respectively. Group I had the highest number of accessions, being composed of three species belonging to subgenus Passiflora (P. quadrangularis, P. nitida and P.cincinnata) and one (P. micropetala) belonging to subgenus Decaloba. Groups II and III were formed by two accessions each; however, group II only allocated species belonging to subgenus Decaloba $(P$. suberosa, P. morifolia) and group III species of two subgenera, P. eichleriana (Passiflora) and P. tenuifila (Decaloba) (Table 3).

This grouping technique allowed separating Passiflora accessions based on quantitative seed characteristics. In addition, it was possible to observe that $P$. edulis was separated from other accessions, presenting the highest values for germination characteristics (93\% germination and $2.76 \mathrm{IVG})$, the same occurred with $P$. mucronata, which presented the 
highest emergence percentage value.

In relation to the relative contribution of characters to the genetic diversity among accessions (Table 4), based on criteria proposed by Singh (1981), it can be observed that for the 12 accessions studied, in descending order of contribution, they showed the following characteristics: seed mass, seed length, germination speed index, emergence percentage, germination percentage, seedling dry mass, radicle length and emergence speed index, where it was found that seed mass, seed length and germination speed index contributed with $73.78 \%$ of the total distribution, being considered the most important in the present study.

In studies with papaya genotypes, Cardoso et al (2009) obtained higher contribution of variable mass of one thousand seeds for the genetic diversity using the Singh method.

However, Souza et al. (2012) found greater contributions to the genetic divergence based on the characteristics of seedlings in Passiflora species in variables germination percentage and germination speed index.

Variables, emergence speed index, radicle length and seedling dry mass presented the lowest contribution estimates, and were not important for the evaluation of the general divergence among the 12 Passiflora accessions evaluated.

In view of these study variables, another grouping method, the UPGMA method was used to evaluate the genetic diversity among passion fruit accessions, which is aimed at separating an original group of observations into several subgroups in order to obtain homogeneity within and heterogeneity among subgroups. It uses the mean of distances between all pairs of genotypes for the formation of each group, and is used on a large scale by plant breeders (CRUZ; CARNEIRO, 2006).

Thus, in the present study, it was verified that the dendrogram resulting from the grouping analysis by the UPGMA method (Figure 1), submitted to a cut of about $35 \%$, revealed the formation of four groups, group I composed of accessions 1 ( $P$. quadrangularis), 11 (P. tenuifila), 5 (P. alata) and 7 (P. mucronata), all belonging to subgenus Passiflora.

Group II allocated accessions 8 (P. micropetala) and 10 (P. morifolia) of subgenus Decaloba and accession 6 (P.cincinnata) of the subgenus Passiflora. This group presented accessions with less satisfactory results for the study variables, especially those related to seed vigor (Table 2).

In this sense, it was observed that some species present dormancy in their seeds. Dormancy consists of a survival mechanism, since it can delay germination, an event that occurs when the conditions for establishment are limited and do not favor seed survival (OLIVEIRA, 2012). According to the same authors, during the domestication moment, some species present selection against seed dormancy, making the germination for most of cultivated species fast and uniform, which was not verified in wild species.

Accession 2 ( $P$. nitida) formed a separate group (Group III). This species was close to group II, as it did not present results for variable seed germination; however its separation is mainly due to variables, seed mass and length.

Group IV and group I had the highest number of accessions: 4 (P. eichleriana), 9 (P. suberosa), 12 (P. edulis) and 3 (P. foetida). With the exception of access 12 that belongs to subgenus Passiflora, the others belong to subgenus Decaloba.

In this sense, it was observed that group IV presented a peculiarity, since all its accessions provided the most satisfactory results for all evaluated characteristics, including germination and emergence percentage, which are important for breeding programs aiming at hybridizations (Table 2).

After the Tocher and UPGMA grouping analyses, the Canonical Variables (CV) technique was used. In this sense, in general, when working with genetic diversity, one intends to estimate the similarity / difference among study materials. Therefore, when genetic diversity is verified by the Canonical Variables method, the purpose is to identify similar genotypes in two- or three-dimensional graphic dispersion, making it possible to simplify the interpretation of results. The viability of its interpretation is restricted to the concentration of variability among the first variables, generally above 80\% (CRUZ et al., 2012).

Thus, analyzing the results obtained in this work, it was verified that the first two canonical variables explained $84.98 \%$ of the total accumulated variance, with $\mathrm{CV}_{1}$ accounting for $64.03 \%$ and $\mathrm{CV}_{2}$ for $20.95 \%$ (Table 5 ).

The relative importance of characters was also evaluated in order to identify those of greater and lesser importance for genetic divergence. Seed germination percentage $(64.03 \%)$, seed fresh mass $(20.95 \%)$ and seed length $(10.12 \%)$ were factors that most contributed for the genetic divergence of Passiflora accessions studied by canonical variables method. However, the lowest contribution was seedling dry matter $(0.02 \%)$ and emergence speed index $(0.15 \%)$ (Table 5).

The great interest in evaluating the relative importance of characters lies in the possibility of discarding those that contribute little to the discrimi- 
nation of progenies, thus reducing labor, time and cost spent on experimentation.

Based on the results of the relative importance of characters by the Singh and Canonical Variables methods, it was observed that the sequence of significance was not similar between methods. However, variables seed fresh mass and seed length are among the first three characteristics in both methods. The same occurs with variable seedling dry mass and emergence speed index, which are among the last three characters in terms of importance.

It should be emphasized that in the analysis of the importance of characters by means of Canonic Variables, characteristic germination percentage was the one that contributed the most to the genetic divergence of accessions. This result is important because it discriminates the existence of wide variability of the dormancy degree among accessions and consequently allows the possibility of selecting accessions with greater or lesser dormancy degree depending on the breeding program.

For Cardoso et al. (2009), working with papaya genotypes, the identification of the genetic variability related to seed germination characteristics allowed distinguishing genotypes better, allowing good perspectives for selection.

Figure 2 shows the graphic dispersion in the two dimensional space of 12 passion fruit accessions in relation to the first two canonical variables. It was observed that four different groups were formed: group 1, composed of P. edulis (12), P. suberosa (9), $P$. eichleriana (4) and $P$. foetida (3) accessions; group 2, composed of P. mucronata (7), P. tenuifila (11), P. quadrangulares (1) accessions; group 3, composed of P. morifolia (10), P. alata (5) and P. micropetala (8) accessions and group 4 , composed of $P$. cincinnata (6) and P. crisp (2) accessions.

Regarding groupings, Souza et al. (2012) in their genetic diversity studies based on the germination characteristics of Passiflora L. species by the application of the Canonic Variables technique, also included $P$. alata and $P$. micropetala species in the same group.

The most distant accessions were $P$. nitida (2) and P. edulis (12), which are, respectively, those presenting the worst and best results for the evaluated seed characteristics. However, the most similar were P. quadrangularis (1) and P. tenuifila (11).

Accessions that formed groups 1,2 and 3 presented similar distribution in the UPGMA, being allocated, respectively, in groups IV, I and II.

Thus, it was observed that the dispersion of accessions by means of Canonical Variables showed behavior similar to the grouping by the UPGMA method; however, it is worth mentioning that it was different from that represented by the Tocher method. The same did not occur in the studies of Negreiros et al. (2008), which, working with genetic diversity among yellow passion fruit progenies based on seed characteristics, observed that the graphic dispersion by means of Canonic Variables presented behavior similar to the Tocher grouping.

In this context, according to analyses performed to evaluate the genetic diversity among Passiflora accessions, it was inferred that gathering knowledge about aspects of the germination of seeds of several passion fruit species, especially wild species, is fundamental for the propagation and maintenance of germplasm banks. In this sense, Cruz et al., (2011) reported that although the volume of genetic information from molecular markers has increased considerably in genetic diversity studies, the diversity study is still emphasized through phenotypic characteristics, mainly those of quantitative nature; among them the characteristics of seeds that usually present continuous distribution and are determined by several genes. 
TABLE 1- Relation of Passion fruit accessions used in the experiment. University of the State of Mato Grosso, Cáceres, 2012.

\begin{tabular}{|l|c|c|c|c|}
\hline $\mathrm{N}^{\mathrm{o}}$ & $\mathrm{N}^{\mathrm{o}}$ no BAG & Subgênero & Denominação do Acesso & Origem* $^{*}$ \\
\hline 1 & 1 & Passiflora & Passiflora quadrangulares & $\mathrm{UENF}$ \\
\hline 2 & 2 & Passiflora & P. nitida & $\mathrm{UFV}$ \\
\hline 3 & 3 & Decaloba & P. foetida & $\mathrm{UENF}$ \\
\hline 4 & 4 & Decaloba & P. eichleriana & $\mathrm{UFV}$ \\
\hline 5 & 5 & Passiflora & P. alata & $\mathrm{UFV}$ \\
\hline 6 & 8 & Passiflora & P. cincinnata & $\mathrm{UFV}$ \\
\hline 7 & 9 & Passiflora & P. mucronata & $\mathrm{UFV}$ \\
\hline 8 & 10 & Decaloba & P. micropelata & UENF \\
\hline 9 & 11 & Decaloba & P. morifólia & UENF \\
\hline 10 & 12 & Decaloba & P. tenuifila & UENF \\
\hline 11 & 13 & Passiflora & UFV \\
\hline 12 & 14 & Passiflora & P.edulis (UNEMAT/UFV/UENF 50) & UFV \\
\hline
\end{tabular}

*UFV: Federal University of Viçosa and UENF: State University of the Northern Fluminense.

TABLE 2- Averages of the 12 accessions of Passiflora to eight quantitative seed descriptors. UNEMAT, Cáceres-MT, 2013.

\begin{tabular}{lccccccccc}
\hline & & \multicolumn{7}{c}{ Variable } \\
\cline { 3 - 10 } $\mathrm{N}^{\mathrm{N}}$ & Species & $\begin{array}{c}\text { Fresh mass } \\
\text { Seed }\end{array}$ & $\begin{array}{c}\text { Seedling } \\
\text { germination } \\
\text { Percentage }\end{array}$ & $\begin{array}{c}\text { Germination } \\
\text { speed index }\end{array}$ & $\begin{array}{c}\text { Seedling } \\
\text { emergence } \\
\text { percentage }\end{array}$ & $\begin{array}{c}\text { Emergence } \\
\text { speed index }\end{array}$ & $\begin{array}{c}\text { Seedling } \\
\text { dry mass } \\
\text { of seedlings }\end{array}$ & $\begin{array}{c}\text { Radicle } \\
\text { length }\end{array}$ & $\begin{array}{c}\text { Seed } \\
\text { length }\end{array}$ \\
\hline 1 & P. quadrangulares & $3,63 \mathrm{a}$ & $0,00 \mathrm{e}$ & $0,00 \mathrm{e}$ & $50,00 \mathrm{a}$ & $0,58 \mathrm{~b}$ & $0,18 \mathrm{a}$ & $4,76 \mathrm{~b}$ & $0,82 \mathrm{a}$ \\
2 & P. nitida & $1,03 \mathrm{~g}$ & $0,00 \mathrm{e}$ & $0,00 \mathrm{e}$ & $0,00 \mathrm{f}$ & $0,00 \mathrm{e}$ & $0,00 \mathrm{~d}$ & $0,00 \mathrm{e}$ & $0,70 \mathrm{c}$ \\
3 & P. foetida & $1,32 \mathrm{f}$ & $31,00 \mathrm{~d}$ & $2,30 \mathrm{~b}$ & $26,00 \mathrm{c}$ & $0,38 \mathrm{c}$ & $0,01 \mathrm{~d}$ & $5,06 \mathrm{~b}$ & $0,62 \mathrm{~d}$ \\
4 & P. eichleriana & $1,74 \mathrm{e}$ & $39,00 \mathrm{c}$ & $1,36 \mathrm{~d}$ & $29,00 \mathrm{c}$ & $0,75 \mathrm{a}$ & $0,04 \mathrm{c}$ & $5,90 \mathrm{a}$ & $0,48 \mathrm{e}$ \\
5 & P. alata & $2,96 \mathrm{~b}$ & $0,00 \mathrm{e}$ & $0,00 \mathrm{e}$ & $12,00 \mathrm{e}$ & $0,12 \mathrm{~d}$ & $0,02 \mathrm{~d}$ & $3,17 \mathrm{c}$ & $0,73 \mathrm{~b}$ \\
6 & P. cincinnata & $2,26 \mathrm{c}$ & $0,00 \mathrm{e}$ & $0,00 \mathrm{e}$ & $0,00 \mathrm{f}$ & $0,00 \mathrm{e}$ & $0,00 \mathrm{~d}$ & $0,00 \mathrm{e}$ & $0,69 \mathrm{c}$ \\
7 & P. mucronata & $0,94 \mathrm{~h}$ & $0,00 \mathrm{e}$ & $0,00 \mathrm{e}$ & $54,00 \mathrm{a}$ & $0,62 \mathrm{~b}$ & $0,04 \mathrm{c}$ & $3,32 \mathrm{c}$ & $0,44 \mathrm{~g}$ \\
8 & P. micropelata & $0,37 \mathrm{k}$ & $0,00 \mathrm{e}$ & $0,00 \mathrm{e}$ & $0,00 \mathrm{f}$ & $0,00 \mathrm{e}$ & $0,00 \mathrm{~d}$ & $0,00 \mathrm{e}$ & $0,35 \mathrm{i}$ \\
9 & P. suberosa & $0,53 \mathrm{j}$ & $49,50 \mathrm{~b}$ & $1,86 \mathrm{c}$ & $16,00 \mathrm{e}$ & $0,37 \mathrm{c}$ & $0,01 \mathrm{~d}$ & $3,32 \mathrm{c}$ & $0,35 \mathrm{i}$ \\
10 & P. morifólia & $1,75 \mathrm{e}$ & $0,00 \mathrm{e}$ & $0,00 \mathrm{e}$ & $0,00 \mathrm{f}$ & $0,00 \mathrm{e}$ & $0,00 \mathrm{~d}$ & $0,00 \mathrm{e}$ & $0,46 \mathrm{f}$ \\
11 & P. tenuifila & $0,81 \mathrm{i}$ & $0,00 \mathrm{e}$ & $0,00 \mathrm{e}$ & $19,00 \mathrm{~d}$ & $0,39 \mathrm{c}$ & $0,01 \mathrm{~d}$ & $2,66 \mathrm{~d}$ & $0,40 \mathrm{~h}$ \\
12 & P. edulis & $2,10 \mathrm{~d}$ & $93,00 \mathrm{a}$ & $2,76 \mathrm{a}$ & $42,00 \mathrm{~b}$ & $0,58 \mathrm{~b}$ & $0,14 \mathrm{~b}$ & $4,76 \mathrm{~b}$ & $0,61 \mathrm{~d}$ \\
\hline & C CV & 2,97 & 11,09 & 3,88 & 10,85 & 5,02 & 1,22 & 5,57 & 1,55 \\
\hline
\end{tabular}

Means followed by the same letter in the columns do not differ from each other by the Skott-Knott test at a $5 \%$ probability level. 
TABLE 3-Groups of Passiflora accessions established by the Tocher Optimization method, based on genetic dissimilarity among eight seed descriptors.

\begin{tabular}{|l|l|}
\hline Group & Accessions \\
\hline II & P. quadrangulares, P. nitida, P. cincinnata, P. micropetala \\
\hline II & P. suberosa, P. morifólia \\
\hline III & P. eichleriana, P. tenuifila \\
\hline IV & P. mucronata \\
\hline V & P. alata \\
\hline VI & P. edulis \\
\hline VII & P. foetida \\
\hline
\end{tabular}

TABLE 4-Relative importance of eight quantitative characteristics of seed evaluated in 12 accessions of passion fruit obtained by the Singh method (1981).

\begin{tabular}{|l|c|c|}
\hline Variable & Value (\%) & Value Accumulated (\%) \\
\hline Mass seed & 30,73 & 30,73 \\
\hline Seed lenght & 26,37 & 57,10 \\
\hline Germination speed index & 16,68 & 73,78 \\
\hline Seedling emergence percentage & 10,33 & 84,11 \\
\hline Seedling germination percentage & 8,53 & 92,64 \\
\hline Seedling dry mass & 3,93 & 96,57 \\
\hline Radicle length of seedlings & 2,24 & 98,81 \\
\hline Emergence speed index & 1,19 & 100 \\
\hline
\end{tabular}

TABLE 5-Estimates of the eigenvalues $\left(K_{\mathrm{i}}\right)$, the cumulative variation (\%) and the relative importance of the characters, explained by the Canonical Variables $\left(\mathrm{VC}_{\mathrm{i}}\right)$.

\begin{tabular}{|c|c|c|c|}
\hline $\mathrm{VC}_{\mathrm{i}}$ & $\kappa_{\mathrm{i}}$ & \% Accumulated & Importance of characters in eigenvectors \\
\hline $\mathrm{VC}_{1}$ & 64,035 & 64,035 & Seedling germination percentage \\
\hline $\mathrm{VC}_{2}$ & 20,950 & 84,985 & Mass seed \\
\hline $\mathrm{VC}_{3}$ & 10,123 & 95,108 & Seed lenght \\
\hline $\mathrm{VC}_{4}$ & 2,959 & 98,068 & Seedling emergence percentage \\
\hline $\mathrm{VC}_{5}$ & 1,185 & 99,253 & Radicle length of seedlings \\
\hline $\mathrm{VC}_{6}$ & 0,569 & 99,822 & Germination speed index \\
\hline $\mathrm{VC}_{7}$ & 0,156 & 99,979 & Emergence speed index \\
\hline $\mathrm{VC}_{8}$ & 0,020 & 100,000 & Seedling dry mass \\
\hline
\end{tabular}




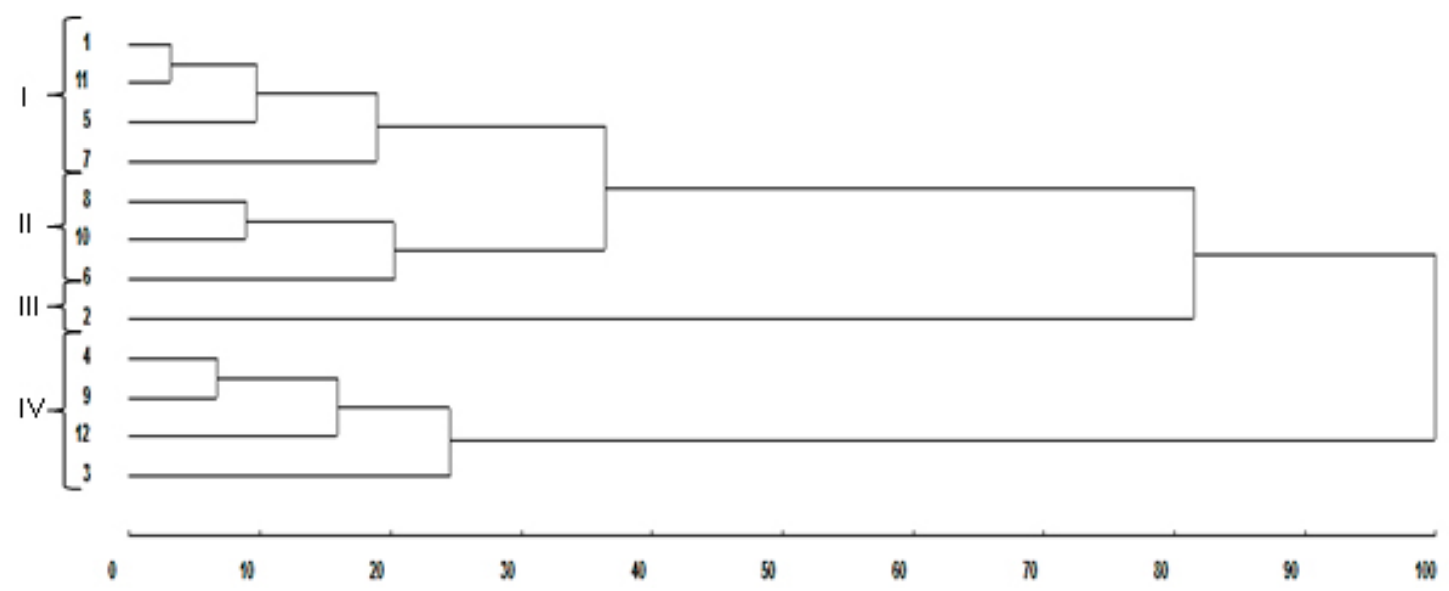

FIGURE 1-Representative dendrogram of the genetic divergence among 12 accessions of passion fruit, obtained by the UPGMA Hierarchical Grouping method based on eight seed characteristics. Cáceres-MT, 2013. (co-phenotype correlation coefficient $=0.71$ ).

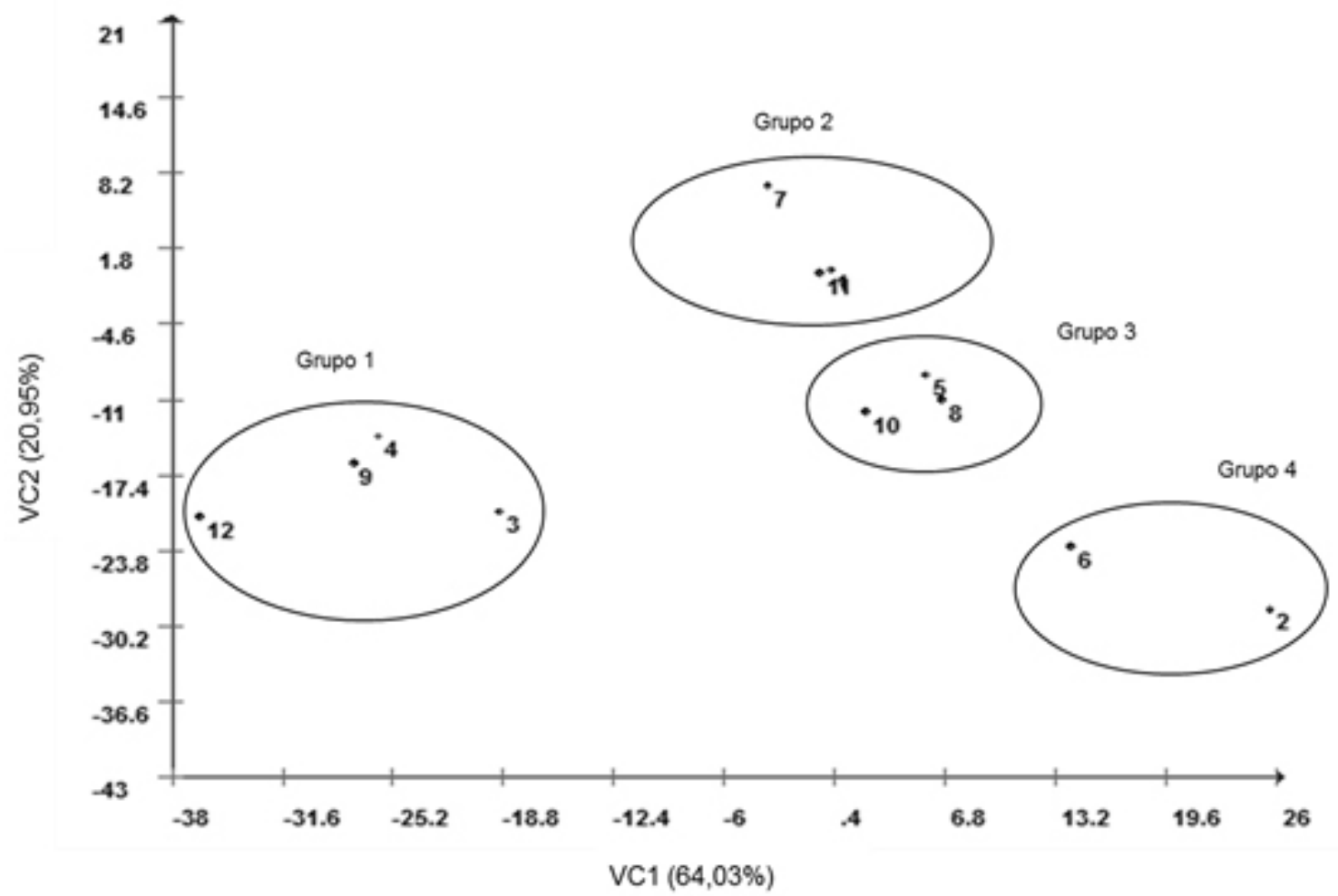

FIGURE 2- Graphic dispersion of the first two canonical variables representing the formation four groups of Passiflora spp. 


\section{REFERENCES}

AZEVEDO, M.M.A.; BAUMGRATZ, J.F.A. Passiflora L. subgênero Decaloba (DC.) .chb. (Passifloraceæ) na região Sudeste do Brasil. Rodriguésia, Rio de Janeiro, v.55, p.54-60, 2004.

BERNACCI, L.C.; CERVI, A.C.; MILWARD-DEAZEVEDO, M.A.; NUNES, T.S.; IMIG, D.C.; MEZZONATO, A.C. Passifloraceae In: INCT. Lista de espécies da Flora do Brasil. Jardim Botânico do Rio de Janeiro. 2013. Disponível em: $<$ http:// floradobrasil.jbrj.gov.br/jabot/floradobrasil $>$. Acesso em: 02 dez. 2016.

BEWLEY, J.D.; BRADFORD, K.J.; HILHORST, H.W.M.; NONOGAKI, H. Sementes: fisiologia do desenvolvimento, germinação e dormência. New York: Springer, 2014. v.1, 407p.

BRASIL. Ministério da agricultura, pecuária e abastecimento. Regras para análise de sementes/ Ministério da agricultura, pecuária e abastecimento. Brasília: Mapa/ACS, 2009. v.1, $395 p$.

CARDOSO, D.L.; SILVA, R.F.; PEREIRA, M.G.; VIANO, A.P.; ARAÚJO, E.F. Diversidade genética e parâmetros genéticos relacionados à qualidade fisiológica de semente em germoplasma de mamoeiro. Revista Ceres, Viçosa, MG, v.56, p.572-579, 2009.

CRUZ, C. D. Genes Software: extended and integrated with the R, Matlab and Selegen. Acta Scientiarum, Maringá, v.38, p.547-552, 2016.

CRUZ, C.D.; CARNEIRO, P.C.S. Modelos biométricos aplicados ao melhoramento genético. 2.ed. Viçosa: Editora UFV, 2006. 585p.

CRUZ, C.D.; FERREIRA, F.M.; PESSONI, L.A. Biometria aplicada ao estudo da diversidade genética. Viçosa: Editora UFV, 2011. v.1, 480p.

CRUZ, C.D.; REGAZZI, A.J.; CARNEIRO, P.C.S. Modelos biométricos aplicados ao melhoramento genético. 2.ed. Viçosa: Editora UFV, 2012. 514p.

O, F. G.; JUNQUEIRA, N. T. V.; BRAGA, FERREIRA, D. F. SISVAR: um programa para análises e ensino de estatística. Revista Symposium, Recife, v.6, p.36-41, 2008.
HADAS, A. Water uptake and germination of leguminous seeds under changing external water potential in osmotic solution. Journal of Experimental Botany, Lancaster, v.52, p.480-489, 1976.

MAGUIRE, J.D. Seep of germination-aid seedling emergence and vigor. Crop Science, Madison, v.2, p.176-177, 1962.

MELO, A.L.; OLIVEIRA, J.C.; VIEIRA, R.D. Superação de dormência em sementes de Passiflora nítida H.B.K. com hidróxido de cálcio, ácido sulfúrico e ácido giberélico. Revista Brasileira de Fruticultura, Jaboticabal, v.22, n.2, p.463-467, 2000.

NEGREIROS, J.R.S.; ALEXANDRE, R.S.; ÁlVARES, V.S.; BRUCKNER, C.H.; CRUZ, C.D. Diversidade Genética entre Progênies de maracujazeiro-amarelo com base em características das plântulas. Revista Brasileira de Fruticultura, Jaboticabal, v.30, p.197-201, 2008.

OLIVEIRA, O. dos S. Tecnologia de sementes florestais: espécies nativas. Curitiba: UFPR, 2012. 406p.

R CORE TEAM. R: A langueige and evironment for statistical computing. Viena: R Foundation for Statistical Conputing, 2012.

SANTOS, T.M. Germinação e dormência de sementes de passifloráceas e seleção de genótipos resistentes à fusarium spp. 2015. 139 f. Tese (Doutorado em Fitotecnia)- Universidade Federal de Viçosa, Viçosa, 2015.

SINGH, D. The relative importance of characters affecting genetc divergence. The Indian Journal of Genetics and Plant Breeding, New Delhi, v.41, p.237-245, 1981.

SOUZA, S. A. M.; MARTINS, K. C.; AZEVEDO, A. S.; PEREIRA, T. N. S. Fenologia reprodutiva do maracujazeiro-azedo no município de Campos dos Goytacazes, RJ. Ciência Rural, Santa Maria, v.42, p.1774-1780, 2012.

TEKRONY, M. D.; EGLI, D. B. Relationship of seed vigour to crop yield: a review. Crop Science, Madison, v.31, p.816-822, 1991. 